\author{
Linguistik Terapan 14(3) (2017): 265-273
}

Jurnal Linguistik Terapan Pascasarjana

Available online http://jurnal.unimed.ac.id/2017/index.php/JLT-

Unimed

\title{
DEVELOPING ENGLISH READING MATERIALS THROUGH QUANTUM LEARNING MODEL FOR LIGHT MOTOR VEHICLE ENGINEERING STUDENTS IN SMK NEGERI 1 PERBAUNGAN
}

\author{
Muvidah \\ I Wayan Dirgayasa Tangkas \\ Eddy Setia
}

Diterima September 2017; Disetujui Oktober 2017; Dipublikasikan Desember 2017

ABSTRACT

The purpose of this study are; 1) to examine the existing reading materials used today by the students of light motor vehicle program; 2) to find out the reading materials needed by the students of light motor vehicle program; 3) to develop the reading materials students of light motor vehicle program based on quantum learning model. This study is descriptive qualitative research. This study inspired by ten stages of Educational Research and Development model by Gall, Gall and Borg, 2003, but in implementing the model is simplified and adapted to Dirgayasa (2011) become four steps: 1) Evaluation and need analysis, 2) designing new material, 3) validating material, 4) revision and final production. The Instrument of collecting the data was collected by questionnaire, documentation and interview. The result of this study showed that the students agree that they really need the relevant material which proper to their program and the analysis of the existing reading material and the existing syllabus showed that the both are less relevant for English reading skill for light motor vehicle students. From evaluation research of documentation and interview agreed that the developing of reading material for light motor vehicle is needed combined with the quantum learning model. the final result of this developing material through quantum learning become some activities; enrolling, experience, labeling, demonstration, review and celebrate and with new title which has correlation with light motor vehicle program they are: 1) Introduction world of automotive; 2) Introduction to tools used by mechanics; 3) Safety rules automotive maintenance safety; 4) How cars work; 5) Light vehicle clutch system; 6) General maintenance.

Keywords: reading materials, light motor vehicle program, quantum learning model. 
How to Cite: Muvidah (2017). Developing English Reading Materials Through Quantum Learning Model For Light Motor Vehicle Engineering Students In Smk Negeri 1 Perbaungan. Jurnal Linguistik Terapan Pascasarjana Unimed, 14 (3): 265-273

ISSN 2407-7410

\section{INTRODUCTION}

Light Motor Vehicle program is one of branch from engineering program which is one of the programs that exist in vocational school.This program becomes favorite program because the students who has graduate have some skills and able to make their own business, so the graduate of this course should have some advantages in between should be able to compete with the current market demand. Therefore improve the skills of the students are not only concerned with the expertise alone but can be balanced with subjects that could support their career level more example to obtain employment industry in the world that requires a few things that must be mastered by graduates as English language related to engineering.

Unfortunately in the reality, the largest proportion content of materials is not suitable with the students in the vocational schools especially for light motor vehicle program. In SMK N 1 Perbaungan. The existing reading materials do not relate with their professionalism. For instance, chapter I about hobbies and dealing with daily activities meanwhile the text is given with the title "Bunaken: Breathtaking Underwater Life", this text does not appropriate with the students needs for light motor vehicle program so that they can not reach their knowledge were based on their needs, the text was too general for them.

From the explanation above, we can conclude that what is being taught should be perceived by learners as relevant and useful. In ESP, teacher of English can easily select materials are relevant to the specific choice of topics and tasks that the learners are also learning in their field of study, therefore, the materials they learn can be applied in their job area directly.Through ESP, students will find some teaching materials which are related to the vocations that they have. Thus, it will be interesting for the students to read the text, and finally the text will enrich the students' knowledge about their vocation. In other words, by having ESP, students will learn English based on what they need.

Nowadays so many innovations and creations are made by some education experts to improve the teaching and learning quality, especially in English classroom. One of the innovations is quantum teaching and quantum learning. This method has become popular recently. Since the method makes the classroom more effective and the students enjoy the lesson.

From all aspect above this study attempted to be implemented Quantum learning approach in light motor vehicle program especially in reading materials students. Therefore the study of developing material of reading for the light motor vehicle program through 
quantum learning approach should be carried on. It will consider can help the English teacher to teach effectively and learners to be more interested and motivated in learning English.

\section{REVIEWOF LITERATURE}

English for Specific Purpose (ESP) is a branch of English Language Teaching and refereed as applied ELT as the aims and contents of any ESP courses is based on specific needs of the learners (Pradhan, 2013).Students learn ESP represented by studying subject matter to gain and develop appropriate knowledge and skills through English (Burdova, V. 2007). With interactive program and provide cooperative learning in studying English to their needs the learners will see the effectiveness of their learning. The students will have a high motivation and make learning English in their purpose will be focus, better and faster.

Course design is the process by which the raw data about a learning need is interpreted in order to produce an integrated series of teaching-learning experiences. (Hutchinson and Waters, 1987). It means that in the process need some data about learning need that must be connected with the selected series activities in order to make the pleasant of learning situation.

ESP materials are not selected solely to transform information from teacher to learners (Imane, 2013). In fact the teacher must be selected for educational purposes as well as for fun and motivation. If the teacher does not think of this side, learners would not be satisfied and happy concerning what are they are learning. Thus, the teacher should focus on what attracts the students for the learning process. (Hutchinson and Waters, 1987).

Conducting the need analysis as the part of ESP in order to make the learning become language-centred approach there is a target need that can identify the general heading of need.The purpose of need analysis according to Dudley-Evans \& St. John (1998) is to establishing what and how the material will be design. The outcome of a need analysis should be a list of goals and objectives for the parties involved, which should "serve as the basis for developing test, materials, teaching activities and evaluation strategies as well as for reevaluating the precision accuracy of the original needs assessment".(Okeke et al. 2011).

There are many items that the students of light motor vehicle learn in their major. Some skills and knowledge have to gain at school with doing theories and practices. According to Denton (2011) there are some knowledge about automotive engineering such as;

\section{Working health and safety in automotive industry.}

Working health and safety for students when they are doing practice at work shop or when the students have to go to the practical industry, the students must have a right to work in places where risks to their health and safety are properly controlled. Health and safety is 
about stopping the students to getting hurt at work. In this term the teacher will teach about what the students which is they can do or not; about personal protective equipment, knowing and identifying about hazards, safety procedures, sign and so on.

\section{Introduction about tools, materials and measuring devices in light motor} vehicle.

To make sure that the students will use some tool properly the students must know the tools that they will use for operating or service the materials of the automotive. Removing, refitting and adjusting components to ensure that vehicle system operates within specification is a summary of almost all the work that the students will be doing. The operation and care of some equipments will vary with different types, therefore the students should always read the manufacture's instruction carefully before use, or if the students will face some problems.

\section{Skills and knowledge in routine light vehicle maintenance}

The purpose of routine maintenance is to keep the vehicle in good working order and in safe condition. It is usually a condition of the warranty that a vehicle should be services according to the manufacturer's need. So the students should know the way and good skills for doing correct adjustment or the students will make the trouble.

Quantum learning design consisting of six stages is bound to correlative and mutual complementary principle. The design consists of enrolling, experiencing, labeling, demonstrating, reviewing, and celebrating. This phases should cover academic and life long learning skills effectively (DePorter, Readon and Nourie, 2000, Suryani, 2013, Bahaddin and Yusuf , 2014, )

Quantum learning model taken because quantum learning covers tips, hints, strategies and the whole process of learning that can be sharpen the understanding of memory and learning as an enjoyable process and meaningful one. Some researchers who have done some research mention that quantum learning has great advantages in order to help the students' achievement of learning. It will make the learning process will be easier and fun to reach the goal of teaching learning process.

\section{RESEARCH METHODOLOGY}

This research was conducted at SMKN 1 Perbaungan and the targets of this research are the students of Light Motor Vehicle Department academic year 2016/2017. The target clients of this research were the number of research subjects totally reach 23 respondents, namely the students of light motor vehicle department grade XI of 2016/2017 academic years, they are taken by random sampling technique, a) students, b) English teacher and c) stake holder.

Basically, this research followed the procedures of Research and Development model by Gall, Borg and Gall's (2003). However, the procedures are not a strict step that should be implemented. As Dirgayasa (2011) said that the procedures of development and research implementation are not strict steps that should be followed, every researcher can execute and 
determine the proper procedures for him/her based on the condition faced during the process of development. It can be said that the researcher can modify the procedures according to his/her condition. Then, the steps of materials development are modified in to four steps, they are: 1) evaluation and need analysis; 2) course design;3) materials validation; 4) revision and final production.

The research instruments were developed to measure and evaluate the process of teaching English reading material for students of light motor vehicle are questionnaire form likert scale, interview and documentary sheet.

First, the questionnaire from likert scale consists of five options that is a) very good, b) good, c) fair, d) poor, and e) very poor. This instrument was used to collect data both from the students and teachers dealing with the current and existing teaching and learning process of light motor vehicle department. However, the items of questionnaire are same between the students and the lectures. The instrument filled in by students was used to collect the data from the students' perspectives whereas the instrument answered by the teacher was used to have the data from teacher's perspectives about the process of light motor department teaching and learning. This data also included target need learning materials in terms of contents, learning strategies and learning materials design.

Second, The interview sheets. In the form of interview sheet was also used to collect the data for need analysis. It was applied to the Engineering teachers, alumni and stakeholder. The interview was applied by using transcribes them into the writing form. This instrument can be used to support the data collected by previous instruments questionnaire and documentation sheet.

Finally, documentary sheet; the documentary sheet was also used to collect the data dealing with the students record and other related documents. Documentary sheet was used to collect the existing data such as syllabus, existing materials.

\section{DATA ANALYSIS}

\section{The Evaluation and Need Analysis}

The evaluation was done for knowing about the compatibility of the existing materials with the situation of learning in English especially for reading. The evaluation was done by the researcher by collecting the documentation. The documentation was done to examine the compatibility of the existing materials with the students need. The checklist of syllabus was done for evaluating the syllabus adapted from Cunningsworth in Richard, 2011.

The findings of the existing reading materials the objective of the existing reading materials are not appropriate with the students' skill. The arrangement of the book interrelated one and the other and there are not the progress that can be connected and support from the previous topic to the next topic. In term of linguistics feature, there are not provided about vocabularies about the text are given and how to pronounce it. About the topics are given, irrelevant with the students' expertise program. In term of learning method there is not certain learning methods to help students for helping the students learn reading 
text easily and can not motivate the students because the existing reading materials can not apply activities based learning from the text are given. And about the skills doesn't help the students to improve students' reading skills quickly and can not be combined with other language skills.

Need analysis as the important source data after evaluation process. To collect the data was collected from stake-holder, alumni, engineering teacher and students of light motor vehicles. Stake-holder is the place for the alumni to find the job which is appropriate with their program, so the information about the material should be gain from stake-holder. The alumni is the graduate students that already studied at school, so they have information to the teacher whether the English subject that already studied at school has big contribution for their work place. The engineering teacher is giving the compatibility with the engineering syllabus so the developing material out of the way for class XI.

Based on target needs result showed that from stake-holder they need the employees that can understand English well especially in reading text because there are some area used English such as they have to read the Standard of Operation (SOP) in the work shop used English. Introduction to tools, about part of the car include the body and also about the engine part in English too. The safety rules and how the way to maintenance and repair the car they have to read some important text in the manual book in English. Meanwhile from the alumni said that it is very important for vocational school especially for light motor vehicle program to prepare the reading text which is appropriate for the students (authentic material). Because the topic in English book doesn't provide the text about engine or anything about light motor vehicle, so they felt difficult in their work shop. From engineering teacher said that there are some topics which have to be learned by class XI students about how cars works, part of body, tools, maintenance, safety rules with the environment.

\section{Developing New Material}

Developing of new material is related to the result of all evaluation aspect such as

syllabus, existing material and learning activities and the most important is the result of need analysis was done by the students as the source of the data. The student's need analysis is very important because from this data will know about the materials should be used. In the developing process the skill syllabus is as well as establishing criteria for the ordering and adaptation of text, will probably also play a role in their initial selection. At the same time, the texts available will affect what can be focused on in exercise and assessment, in this process has some activities should be done;

\section{a. Drafting of Reading Material}

In developing materials, it needs to prepare the first draft of a good construction. It will be assumed the printed text version that will be developed in line with the current 
curriculum at light motor vehicle program. In reading text draft can be done by three ways. First, the materials were taken from any sources, and then it is classified with the appropriate topics that are suitable for light motor vehicle program and support of student's need. Second, the topics that have been chosen showed to the vocational teacher to match with the existing curriculum. Third, in terms of vocabulary was taken from the text and make the pronunciation word in the developing material. Concerning with the research in the first way that is adopted the materials and developing for appropriate with the student's need.

\section{b. Reading Material in Quantum Learning Model}

In developing materials can be combined with an interesting learning model to be able to improve student learning motivation and help improve student achievement. It supported by the Hutchinson and Waters, (1987) said that a good instructional material should provide a stimulus to learning. It means that a good material should be interesting and contain enjoyable activities. To realize the learning process interesting and fun then used the learning model of quantum learning to support the development of this material.

Quantum learning design contain of six stage is bound to correlative and mutual complementary principle. The designs consist of enrolling, experiencing, labeling, demonstrating, reviewing and celebrating.

\section{Reviewing}

After the draft of the teaching materials is completed, then the initial assessment of the draft of the teaching materials is conducted.Assessment of teaching materials involved in peer review by a teacher. Assessment is conducted to obtain comments, inputs and suggestions as well as constructive criticism from peers in an effort to improve the feasibility of teaching materials from the point of view of teachers who teach in the light motor vehicle program.Peer assessment becomes important in the early stages of development of teaching materials.

\section{Revising}

After got the result of assessment by the peer so the revise would have done by doing from input, suggestion and comment.

a. The size of the book has changed with the bigger and the cover has changed and printed by good paper.

b. The grammars in task of reading comprehension have been revised.

c. In Enrolling stage have made some more activities such as watching video.

\section{Validation}

The validity of the product was determined base on the result of the judgment. There were two experts were involved in evaluating the product. The experts were Dr. Anni H. Pulungan, M.Hum as the first expert. She is a lecture from State University Medan and a teacher of light motor vehicle form SMK Negeri 1 PerbaunganEkoSusiloSitanggang, S.Pd as the second expert. This table is the result of corrections, suggestions and comments for the book. The data was taken from questionnaire that has given to the expert and it was analyzed 
using descriptive technique. The questionnaire consist a set of questions and statement in the form of likert scale. It consist of five option that is value 5 (very good), 4 (good), 3 (fair/enough), 2 (poor) and 1 (very poor) adopted from Dirgayasa (2011).

The result of expert judgment of the developing reading material for light motor vehicle.

\begin{tabular}{|c|c|c|c|c|}
\hline No & Aspects & \multicolumn{2}{|c|}{ Expert } & Total \\
\hline & & E1 & E2 & \\
\hline 1 & Contents & 33 & 36 & 69 \\
\hline 2 & Process & 38 & 33 & 71 \\
\hline 3 & Curriculum & 14 & - & 14 \\
\hline 4 & Linguistic features & - & 15 & 15 \\
\hline \multirow[t]{3}{*}{5} & Lay out & 23 & 24 & 47 \\
\hline & Total & 108 & 108 & 216 \\
\hline & \multicolumn{3}{|c|}{ Average } & 108 \\
\hline
\end{tabular}

From the average from the score of validation from the experts got 108 (the parameter shown at table 3.4), it means the product in the level of feasible got excellent.

\section{CONCLUSION AND SUGGESTION}

Developing of reading material for light motor vehicle is needed combined with the quantum learning model. the final result of this developing material through quantum learning become some activities; enrolling, experience, labeling, demonstration, review and celebrate and with new title which has correlation with light motor vehicle program they are: 1) Introduction world of automotive;, 2) Introduction to tools used by mechanics; 3) Safety rules automotive maintenance safety; 4) How cars work; 5) Light vehicle clutch system; 6) General maintenance.

To English teacher at vocational school suppose giving more attention to the students need in learning English. It is not only prepare them to face national examination but as a teacher we should prepare them to be able in face the competition to look for a job after they graduate from the school.

\section{REFERENCES}

Denton, Tom. 2011. Automobile Mechanical and Electrical System: Automotive Technology Vehicle Maintenance and Repair. Oxford: ELSEVIER Ltd.

DePorter, B., Hernacki, M. 2013.Quantum Learning: Membiasakan Belajar Nyaman dan Menyenangkan. Bandung: MizanPustaka Press. 
DePorter, B., Reardon M. and Nourie S. S. 2000.Quantum Teaching: Memperaktikkan Quantum Learning di Ruang-RuangKelas. Bandung: MizanPustaka Press.

Dirgayasa, Wayan, I . 2011. Bahan Ajar Menulis Bahasa Inggris untuk Tujuan Khusus ESPMaritime English Berbasis Genre. Studi Penelitian dan Pengembangan di Akademi Maritim Indonesia Medan. UNJ: Jakarta.

Dudley-Evans, T. 1998.Developments in English for specific purposes: A multi-disciplinary approach. Cambridge: Cambridge University Press.

Dudley-Evans, T. 1998.Developments in English for specific purposes: A multi-disciplinary approach. Cambridge: Cambridge University Press.

Gall, M.D, J.P., \& Borg, W.R. 2003.Educational Research: An introduction (7 $7^{\text {th }}$ Ed.). USA: Pearson Education.

Hutchinson et al. 1987. English for Specific purposes: A learning centered approachCambridge: Cambridge University Press.

Imane, B. A. N. E. 2013. ESP Materials Selection: The Case of Second Year Computer Science Students at Ourargla University.

Okeke.N.U, et al. 2011.English for specific purposes. Lagos: National Open University of Nigeria.

Pradhan, A. 2013.English for Specific Purposes: Research Trends, Issues and Controversies. Issue 40,Vol. 4. 